\title{
Role of Tamm-Horsfall protein and uromodulin in calcium oxalate crystallization
}

M. Carvalho ${ }^{1,2}$, R.A. Mulinari2 and Y. Nakagawa ${ }^{1}$

\author{
${ }^{1}$ Kidney Stone Program, Division of Biological Sciences and the \\ Pritzker School of M edicine, University of Chicago, Chicago, IL, USA \\ ${ }^{2}$ Departamento de Clínica Médica, Hospital de Clínicas, \\ Universidade Federal do Paraná, Curitiba, PR, Brasil
}

\section{Correspondence \\ M. Carvalho \\ Rua Chichorro Jr., 144, Apto. 142 \\ 80035-040 Curitiba, PR \\ Brasil \\ Fax: + 55-41-262-7658 \\ E-mail: carvalho@mais.sul.com.br}

Received December 14, 2001

Accepted August 6, 2002

\section{Abstract}

One of the defenses against nephrolithiasis is provided by macromolecules that modulate the nucleation, growth, aggregation and retention of crystals in the kidneys. The aim of the present study was to determine the behavior of two of these proteins, Tamm-Horsfall and uromodulin, in calcium oxalate crystallization in vitro. We studied a group of 10 male stone formers who had formed at least one kidney stone composed of calcium oxalate. They were classified as having idiopathic nephrolithiasis and had no well-known metabolic risk factors involved in kidney stone pathogenesis. Ten normal men were used as controls, as was a group consisting of five normal women and another consisting of five pregnant women. Crystallization was induced by a fixed supersaturation of calcium oxalate and measured with a Coulter Counter. All findings were confirmed by light and scanning electron microscopy. The number of particulate material deposited from patients with Tamm-Horsfall protein was higher than that of the controls $(\mathrm{P}<0.001)$. However, Tamm-Horsfall protein decreased the particle diameter of the stone formers when analyzed by the mode of the volume distribution curve $(\mathrm{P}<0.002)(5.64 \pm 0.55 \mu \mathrm{m}$ compared to $11.41 \pm 0.48 \mu \mathrm{m}$ of uromodulin; $15.94 \pm 3.93 \mu \mathrm{m}$ and $12.45 \pm 0.97 \mu \mathrm{m}$ of normal men Tamm-Horsfall protein and uromodulin, respectively; $8.17 \pm 1.57 \mu \mathrm{m}$ and $9.82 \pm 0.95 \mu \mathrm{m}$ of normal women Tamm-Horsfall protein and uromodulin, respectively; $12.17 \pm 1.41$ $\mu \mathrm{m}$ and $12.99 \pm 0.51 \mu \mathrm{m}$ of pregnant Tamm-Horsfall protein and uromodulin, respectively). Uromodulin produced fewer particles than Tamm-Horsfall protein in all groups. Nonetheless, the total volume of the crystals produced by uromodulin was higher than that produced by Tamm-Horsfall protein. Our results indicate a different effect of Tamm-Horsfall protein and uromodulin. This dual behavior suggests different functions. Tamm-Horsfall protein may act on nucleation and inhibit crystal aggregation, while uromodulin may promote aggregation of calcium oxalate crystals.
Key words

- Tamm-Horsfall protein

- Uromodulin

- Calcium oxalate

- Nephrolithiasis 


\section{Introduction}

Human urine is almost always supersaturated with a mixture of various ions and salts, including calcium oxalate $(\mathrm{CaOx})$, which is the most common component of kidney stones (1). It has been accepted that stone formation is a crystallization process taking place in supersaturated urine and that urinary supersaturation is the driving force for the formation of crystal nidus and subsequent stone formation (2). One of the defenses against nephrocalcinosis and nephrolithiasis includes macromolecules (proteins and glycosaminoglycans) that modulate the nucleation, growth, aggregation and retention of crystals in the kidneys (3-6).

Tamm-Horsfall protein (THP) is one of the main components of urinary proteins. It is a glycoprotein produced and secreted by the thick ascendant limb of the loop of Henle, being the most abundant protein in normal human urine, excreted in quantities of 20 to $200 \mathrm{mg} / 24 \mathrm{~h}(7,8)$. THP of normal subjects inhibits the aggregation but has little effect on nucleation and growth of $\mathrm{CaOx}$ crystals (9). However, THP activity is influenced by its own concentration, urinary $\mathrm{pH}$ and ionic strength, playing a dual role in crystal formation depending on the environmental conditions (10). Moreover, THP isolated from the urine of recurrent stone formers sometimes becomes a promoter of $\mathrm{CaOx}$ aggregation due to a tendency to self-aggregation, which removes it from effective interaction with $\mathrm{CaOx}$ monohydrate crystals (11).

Uromodulin (UM) is a protein with immunosuppressive activity in vitro and thought to be present only in urine from pregnant women (12). Preliminary analysis of UM revealed a very high carbohydrate content, a tendency to form aggregates and the presence of intrachain disulfide bridges, characteristics shared by THP (13). Indeed, they have the same protein framework but UM is more heavily glycosylated than THP and contains unprocessed mannose-rich chains
(8). The differences in glycosylation may reveal different functional properties of these two molecules (14).

The aim of the present investigation was to determine the role of THP and UM isolated from urine of normal individuals, pregnant women and patients with nephrolithiasis on calcium oxalate crystallization in vitro.

\section{Material and Methods}

\section{Patients and controls}

We selected 10 male stone formers, who had formed at least one separate kidney stone, with $50 \%$ or more of the stones being composed of $\mathrm{CaOx}$. These patients were referred to us as having idiopathic nephrolithiasis and their urine had no well-known metabolic risk factors for kidney stone pathogenesis (15). As controls, we studied 10 men and 10 women ( 5 of them pregnant) without a personal history of kidney stones, stone formation in family members or any systemic disease known to involve the kidneys. They were age matched with a same-sex patient. Patients discontinued all stone-prevention treatments at least 2 weeks before the urine collection.

\section{Urine chemistry}

Each subject collected one 24-h urine sample using thymol as preservative. Creatinine, calcium, magnesium, phosphate, sodium, potassium, and uric acid were measured in each urine sample using a Beckman Synchron CX5 spectrophotometer (Beckman Instruments, Brea, CA, USA). Oxalate was determined by enzyme assay using oxalate oxidase (Sigma Diagnostics, St. Louis, MO, USA) and citrate was measured enzymatically with citrate lyase (Boehringer Mannheim, Mannheim, Germany). Both enzymatic methods were modified for an autoanalyzer using user-defined chemistry set up systems. 
Isolation of uromucoids (Tamm-Horsfall protein and uromodulin)

Uromucoids were isolated from 24-h individual urine specimens by the method of Tamm and Horsfall (16). Briefly, sodium chloride was added to 24 -h urine to a $0.58 \mathrm{M}$ sodium chloride concentration, stirred constantly overnight at $4^{\circ} \mathrm{C}$, and then centrifuged at $10,000 \mathrm{~g}$ for $30 \mathrm{~min}$ again at $4^{\circ} \mathrm{C}$ with an RC-5 Sorvall refrigerated centrifuge (Sorvall, Newtown, CT, USA). The precipitate was washed once with $0.58 \mathrm{M}$ sodium chloride aqueous solution, dissolved in $1 / 10$ of the original volume of water, and dialyzed against 10 liters of water overnight. The dialyzed uromucoid solution was precipitated again from $0.58 \mathrm{M}$ sodium chloride, and the glycoprotein recovered by centrifugation in the same manner as described above. The uromucoid obtained was dissolved in water, dialyzed overnight, lyophilized, and stored at $-20^{\circ} \mathrm{C}$.

\section{Separation of Tamm-Horsfall protein and uromodulin}

Uromodulin was separated from THP by the method described by Muchmore and Decker (12). Uromucoid precipitated by sodium chloride was dissolved in PBS, passed through a concanavalin A-Sepharose column $(1 \times 2 \mathrm{~cm}$, Pharmacia Biotech, Piscataway, NJ, USA) and washed with 3 bed volumes of PBS to obtain the THP portion. UM was eluted with $250 \mathrm{mM}$ alpha-methylmannoside with 3 bed volumes. Both proteins were further passed through a Sephacryl S200 column $(2 \times 100 \mathrm{~cm}$, Pharmacia) using $50 \mathrm{mM}$ Tris- $\mathrm{HCl}, \mathrm{pH} 7.3$, containing $0.2 \mathrm{M}$ $\mathrm{NaCl}$ and $0.2 \%$ sodium azide. Protein elution was monitored by absorbance at $280 \mathrm{~nm}$ using a Beckman spectrophotometer model DU-650. Protein concentration was determined using an extinction coefficient of 10.8 .

The purity of the proteins was determined by SDS-PAGE. The gels were stained with silver nitrate to detect protein bands. Immunoreactivity was examined using a commercially available polyclonal THP antibody raised in rabbits (Biomedical Technology Inc., Stoughton, MA, USA) using a Nuncimmunoplate. Color was developed with a Vecstastain ABC kit (Vector Laboratories Inc., Burlingame, CA, USA) and absorbance was measured at $405 \mathrm{~nm}$ using a reference wavelength at $630 \mathrm{~nm}$ and an ELISA plate reader (Dynatech Laboratories, Alexandria, VA, USA).

\section{Carbohydrate analysis}

Neutral sugars were analyzed quantitatively by the phenol-sulfuric acid method. A $500-\mu 1$ aliquot of the sample was mixed with $0.3 \mathrm{ml}$ of $5 \%$ phenol aqueous solution (w/v), and $2 \mathrm{ml}$ of concentrated sulfuric acid was added rapidly. The mixture was kept for 30 $\mathrm{min}$ at room temperature, and color intensity was measured at $484 \mathrm{~nm}$. The calibration curve was prepared using 5 to $20 \mu \mathrm{g}$ of glucose solution.

\section{Crystallization assay}

We used a nonseeded system when crystallization was induced by fixed supersaturation to measure the effect of THP and UM on CaOx crystallization (17). Briefly, to a 96wells microtiter ELISA plate we added 250 $\mu \mathrm{l}$ of a solution containing $4 \mathrm{mmol}$ of calcium chloride and $150 \mathrm{mmol}$ of sodium chloride in $20 \mathrm{mmol}$ of sodium acetate buffer, $\mathrm{pH}$ 5.7. Fifty microliters of the protein to be tested was added to give a final concentration of $1 \mu \mathrm{M}$. Finally, crystallization was induced by adding $25-\mu \mathrm{l}$ of $0.5 \mathrm{mmol}$ sodium oxalate. All chemicals were the best grade available and the solutions were filtered through $0.22-\mu \mathrm{m}$ Millipore filters. The assay was performed in a parallel protocol using an ELISA plate to measure the effect of THP or UM at the same time. All experiments were run in duplicate at $37^{\circ} \mathrm{C}$. 


\section{Measurements of crystallization}

The turbidity due to the development of crystallization of each plate was measured at $630 \mathrm{~nm}$ using a microELISA reader (Dynatech Laboratories) before and immediately after the addition of oxalate (zero time), at $3 \mathrm{~min}$ and then at 20-min intervals, for $1 \mathrm{~h}$, with constant shaking at $500 \mathrm{rpm}$. Next, the plate was examined with an inverted light microscope to determine the presence of crystals. The content of each well was transferred in 5 $\mathrm{ml}$ of $20 \mathrm{mM}$ sodium acetate buffer, $\mathrm{pH} 5.7$, containing $300 \mathrm{mM}$ sodium chloride. Immediately, the number, total volume and mode of the volume distribution curve of the crystals formed were determined using a Coulter Counter Multisizer II (Coulter Electronics Ltd., Luton, Beds, England) fitted with a $100-\mu \mathrm{m}$ capillary tube. All counts were corrected for background particulate matter by counting a sample of the electrolyte supporting solution with and without the protein to be studied and by subtracting these values from the raw counts (18). The Coulter Counter was calibrated and checked at the onset and conclusion of each specimen sampling using $10.27-\mu \mathrm{m}$ calibrating spherules. The lowest threshold in this instrument was about $2 \mu \mathrm{m}$.

\section{Scanning electron microscopy}

At the end of the experiment, crystals were separated by filtering through a $0.22-$ $\mu \mathrm{m}$ filter, washed with $1 \mathrm{ml}$ of distilled water, and air-dried at $37^{\circ} \mathrm{C}$. The specimens were mounted on carbon-coated copper grids, fixed on stabs, and coated with gold for 4 min using a Sputter coater (Varian Technics, Warrington, England). Images were obtained with a JEOL scanning electron microscope (model JSM-840A) with an operational voltage of $15 \mathrm{kV}$.

\section{Statistical analysis}

All data are reported as means \pm standard deviation. Samples were compared by $t$-tests and by one-way ANOVA using a standard statistical software (Minitab 11.0, Minitab Inc., College Station, PA, USA).

\section{Results}

The chemical composition of urine from patients was similar to that of matched controls, with no significant difference detected between groups, as shown in Table 1 .

After applying SDS-PAGE and silver ni-

Table 1. Chemical data for unine of nephrolithiasis in patients and control subjects.

\begin{tabular}{lcccc}
\hline Measurement & $\begin{array}{c}\text { Stone formers } \\
(\mathrm{N}=10)\end{array}$ & $\begin{array}{c}\text { Control men } \\
(\mathrm{N}=10)\end{array}$ & $\begin{array}{c}\text { Control women } \\
(\mathrm{N}=5)\end{array}$ & $\begin{array}{c}\text { Pregnant women } \\
(\mathrm{N}=5)\end{array}$ \\
\hline Urine calcium (mg/day) & $238.2 \pm 48.2$ & $248.5 \pm 38.6$ & $241 \pm 54.4$ & $234 \pm 50.9$ \\
Urine oxalate (mg/day) & $36.3 \pm 9.2$ & $33.2 \pm 5.4$ & $32.2 \pm 5.1$ & $29.6 \pm 7.6$ \\
Urine citrate (mg/day) & $581.4 \pm 52.2$ & $603.5 \pm 59.0$ & $622.2 \pm 65.3$ & $644.4 \pm 49.0$ \\
Urine uric acid (mg/day) & $724.1 \pm 95.2$ & $688.3 \pm 63.9$ & $700.6 \pm 70.4$ & $693.8 \pm 67.9$ \\
Urine magnesium (mg/day) & $115.6 \pm 39.3$ & $106.3 \pm 28.8$ & $104.0 \pm 25.6$ & $99.2 \pm 24.6$ \\
Urine phosphate (mg/day) & $1034.7 \pm 201.6$ & $972.9 \pm 211.1$ & $913.2 \pm 161.2$ & $1017.4 \pm 191.7$ \\
Urine creatinine (mg/day) & $1640 \pm 374$ & $1510 \pm 370$ & $1332 \pm 286$ & $1259 \pm 285$ \\
Urine sodium (mEq/day) & $150.2 \pm 37.2$ & $125.8 \pm 57.2$ & $128.6 \pm 36.7$ & $120.8 \pm 42.8$ \\
Urine potassium (mEq/day) & $51.6 \pm 8.6$ & $61.5 \pm 13.9$ & $62.6 \pm 24.6$ & $64.0 \pm 20.9$ \\
Urine volume (I/day) & $1.9 \pm 0.5$ & $1.8 \pm 0.3$ & $2.1 \pm 0.4$ & $2.0 \pm 0.3$ \\
pH & $6.16 \pm 0.4$ & $5.99 \pm 0.4$ & $6.01 \pm 0.3$ & $6.22 \pm 0.7$ \\
\hline
\end{tabular}

Data are reported as means \pm SD. Differences among all groups were not statistically significant. Reference values are: calcium 100-300 mg/day, oxalate $20-45 \mathrm{mg} /$ day, citrate $500-750 \mathrm{mg} /$ day, uric acid $600-800 \mathrm{mg} /$ day, magnesium 50-150 mg/day, phosphate 500-1500 mg/day, creatinine 1000-2000 mg/day, sodium 50-150 $\mathrm{mEq} /$ day, potassium 20-100 $\mathrm{mEq} /$ day, volume $>1.5 \mathrm{l} /$ day, $\mathrm{pH}$ 5.8-6.2. 
trate staining, THP and UM were detected as single bands of $\sim 80 \mathrm{kDa}$. Both proteins reacted against THP antibody raised in rabbits. The apparent content of hexoses in UM was at least 1.3 times higher than that of THP. The concanavalin A-Sepharose column recognized only UM, probably because of exposure of mannose residues due to cleavage of terminal carbohydrate chains such as the Neu/GalNAc/ GluNAc and GalNAc/GluNAc moieties. The urinary excretion rate of THP and UM was similar among stone formers and controls (49 $\pm 1.1 \mathrm{mg} /$ day for THP and $49.3 \pm 1.2 \mathrm{mg} /$ day for UM from stone formers $v s 51 \pm 0.5$ and $49.3 \pm 2.2 \mathrm{mg} /$ day for THP and UM from normal men, respectively; $50.2 \pm 1.9$ and 50.8 $\pm 1.9 \mathrm{mg} /$ day for THP and UM from normal women, respectively; $52 \pm 0.7$ and $51.3 \pm 2.7$ $\mathrm{mg}$ /day for THP and UM from pregnant women, respectively; $\mathrm{P}=\mathrm{NS}$ for all comparisons). The THP/UM ratio obtained for each group was also similar: $1.04 \pm 0.7$ for nonstone-forming males, $1 \pm 0.56$ for patients with nephrolithiasis, $0.91 \pm 0.37$ for normal females, and $0.97 \pm 0.41$ for pregnant women ( $\mathrm{P}$ $=\mathrm{NS}$ ).

The data in Figure 1 report the time course of the measurement of absorbance at 630 $\mathrm{nm}$. After the induction with sodium oxalate there was an initial steady increase of absorbance in all groups in the first $20 \mathrm{~min}$. These curves reached their plateau around $40 \mathrm{~min}$, and some of them slightly decreased after this period of time due to crystal aggre- gation. The stone formers THP curve was significantly different from all other groups ( $\mathrm{P}<0.0001$ for all comparisons) at 40 and 60 $\min$ and also at 3 and $20 \min (\mathrm{P}<0.01)$, except for normal women.

The Coulter Counter data showed that the number of $\mathrm{CaOx}$ crystals formed in the presence of stone formers' THP was significantly higher than the controls $(\mathrm{P}<0.001$, Table 2). However, THP significantly de-

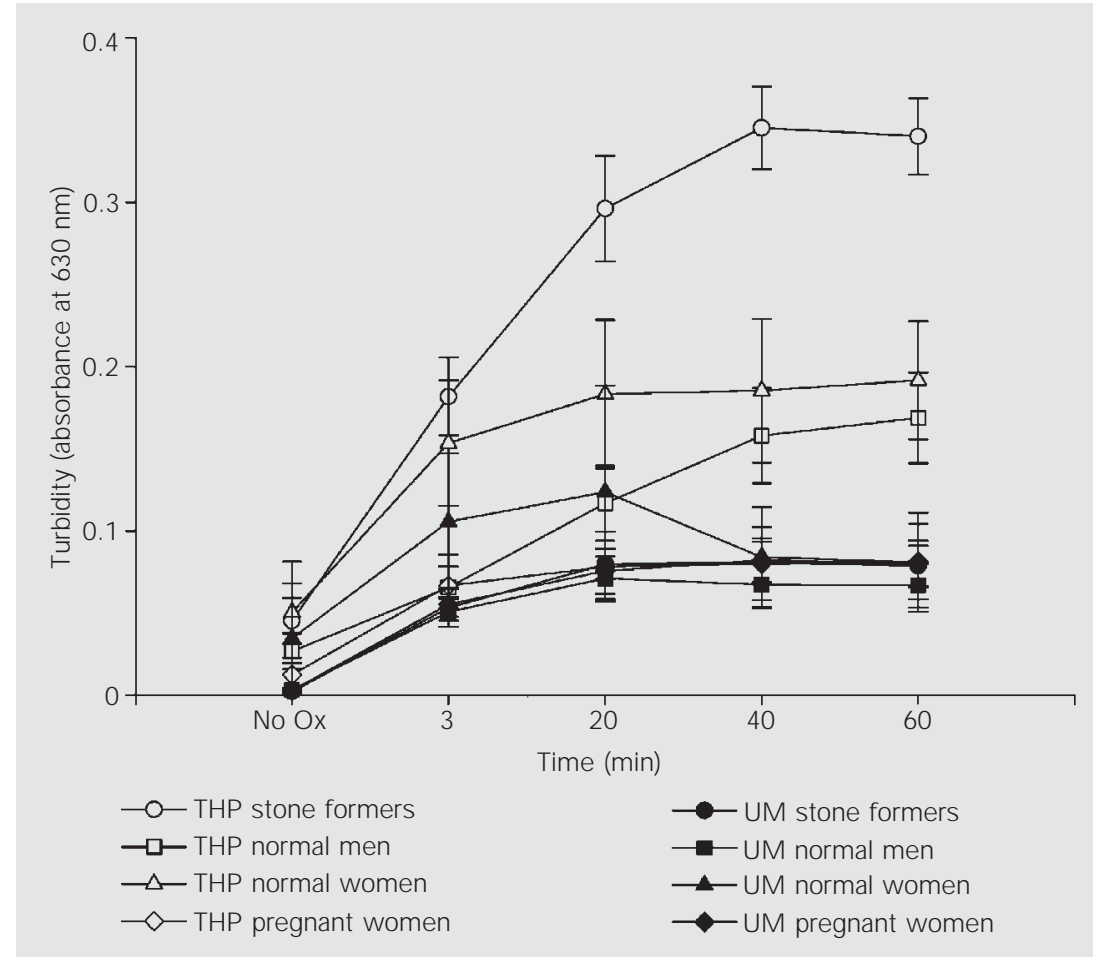

Figure 1. Time course of increased turbidity. Data are reported as means $\pm \mathrm{SD}$ of absorbance at $630 \mathrm{~nm}$. No Ox indicates oxalic acid was not added. THP = Tamm-Horsfall protein; UM = uromodulin.

Table 2. Effects of Tamm-Horsfall protein (THP) and uromodulin (UM) on calcium oxalate crystallization.

\begin{tabular}{|c|c|c|c|c|c|c|c|c|}
\hline \multirow[t]{2}{*}{ Measurement } & \multicolumn{2}{|c|}{$\begin{array}{l}\text { Stone formers } \\
\qquad(N=10)\end{array}$} & \multicolumn{2}{|c|}{$\begin{array}{l}\text { Control men } \\
(N=10)\end{array}$} & \multicolumn{2}{|c|}{$\begin{array}{l}\text { Control women } \\
\qquad(N=5)\end{array}$} & \multicolumn{2}{|c|}{$\begin{array}{l}\text { Pregnant women } \\
\qquad(\mathrm{N}=5)\end{array}$} \\
\hline & THP & UM & THP & UM & THP & UM & THP & UM \\
\hline $\begin{array}{l}\text { Crystal } \\
\text { number }\left(\times 10^{3}\right)\end{array}$ & $53.53 \pm 10.33^{*}$ & $8.76 \pm 1.24$ & $11.05 \pm 2.10$ & $6.19 \pm 0.77$ & $20.02 \pm 5.81^{*}$ & $13.14 \pm 3.72$ & $6.10 \pm 1.21$ & $4.43 \pm 0.42$ \\
\hline $\begin{array}{l}\text { Total crystal } \\
\text { volume (x 106) }\end{array}$ & $1.68 \pm 0.15$ & $2.23 \pm 0.21^{*}$ & $1.22 \pm 0.15$ & $1.26 \pm 0.10$ & $1.51 \pm 0.17$ & $1.63 \pm 0.12$ & $1.24 \pm 0.19$ & $1.21 \pm 0.12$ \\
\hline
\end{tabular}

Data were collected at the end of the experiment $(60 \mathrm{~min})$ and are reported as means $\pm \mathrm{SD}$.

$* \mathrm{P}<0.002$ compared with other groups (one-way ANOVA). 
Figure 2. Effects of TammHorsfall protein from normal men $(A)$ and stone formers $(B)$ on calcium oxalate crystallization (light microscopy, 500X).
Figure 3. Effects of TammHorsfall protein from normal men $(A)$ and stone formers $(B)$ on calcium oxalate crystallization (scanning electron microscopy). creased the particle diameter of the stone formers $(\mathrm{P}<0.002)$, when analyzed by the mode of the volume distribution curve (5.64 \pm 0.55 compared to $11.41 \pm 0.48 \mu \mathrm{m}$ of UM; $15.94 \pm 3.93$ and $12.45 \pm 0.97 \mu \mathrm{m}$ of normal men THP and UM, respectively; $8.17 \pm 1.57$
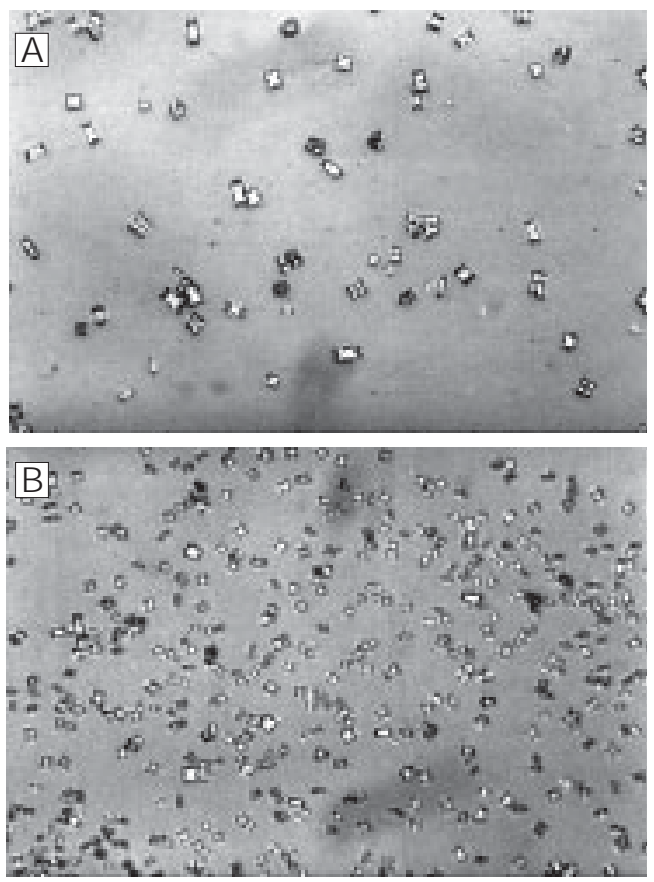

A
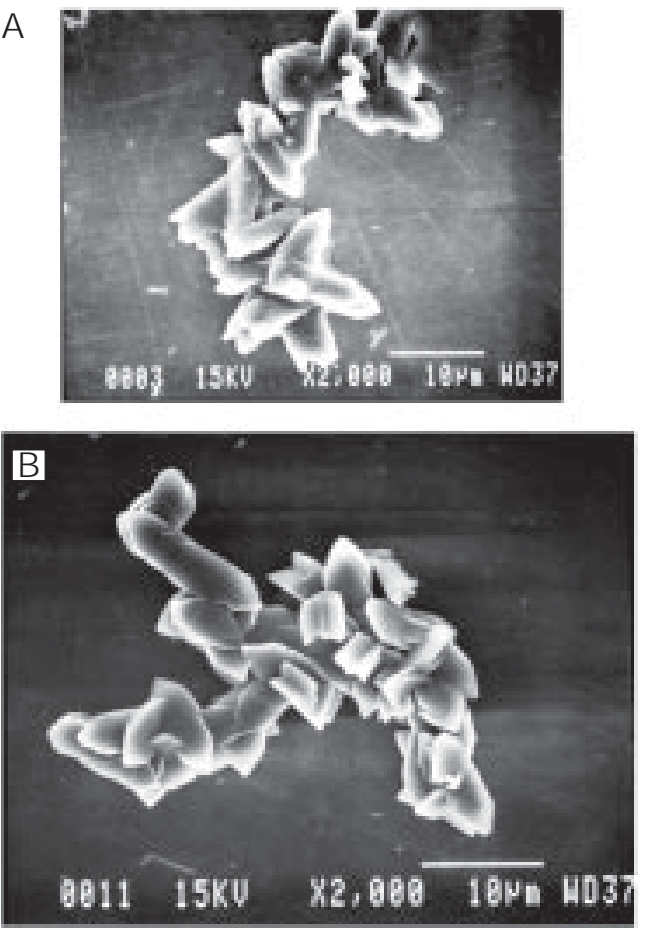

and $9.82 \pm 0.95 \mu \mathrm{m}$ of normal women THP and UM, respectively; $12.17 \pm 1.41$ and $12.99 \pm 0.51 \mu \mathrm{m}$ of pregnant women THP and UM, respectively). UM produced fewer particles than THP in all groups. Nonetheless, the total volume of the crystals produced by UM tended to be larger than THP in controls and the total volume of stone former UM was slightly but significantly different from the UM of THP stone formers and from all other groups (Table 2).

Figures 2-5 show representative light and scanning electron microscopy photographs of crystals formed in the presence of THP and UM from normal men and stone formers, respectively. The THP of the nephrolithiasis group formed a large number of small crystals and preserved the typical $\mathrm{CaOx}$ monohydrate and dihydrate morphology. Uromodulin allowed formation of few crystals of large volume and a wide variety of shapes such as hexagonal plates, mulberry formations, and aggregates.

\section{Discussion}

Urinary tract stones form because of the tendency for urine to be supersaturated with stone salts. However, stone formers have slightly higher levels of supersaturation than non-stone formers, and the distribution of supersaturation within the two populations shows a substantial overlap (19). Urinary inhibitors of crystal growth and aggregation have long been assumed to play a protective role in nephrolithiasis. Urine from patients with recurrent stones contains larger crystals than urine from normal individuals and inhibits crystallization less than normal urine does. These facts support the idea that defective inhibitors could contribute to stone formation (11).

We studied a highly selected population of patients with nephrolithiasis who did not have any of the most common urinary biochemical abnormalities related to kidney stone formation. Using this approach, we 
tried to target stone formers with a high probability of harboring defects in macromolecules that inhibit several steps of crystallization.

THP is one of these macromolecules and has been extensively studied, sometimes with paradoxical results concerning $\mathrm{CaOx}$ crystallization reported by different investigators, depending on the conditions and methods employed. Most authors agree that THP is a weak inhibitor of nucleation and growth, but in solutions with high $\mathrm{pH}$, low ionic strength, and low concentrations of divalent ions, the glycoprotein acts as a powerful inhibitor of $\mathrm{CaOx}$ crystal aggregation (20).

Our results agree with several reports that have shown no significant difference in the daily urinary excretion of THP between normal subjects and patients with nephrolithiasis. This finding led to the hypothesis of structural differences in THP obtained from these groups. In fact, Hess et al. (21) showed that THP isolated from the urine of stone formers contained less carbohydrate (mainly sialic acid) than the THP from control subjects. Although THP and UM have the same amino acid sequence, UM isolated by the concanavalin A method possesses more highmannose oligosaccharides. This protein was considerably more potent in inhibiting antigen-induced $\mathrm{T}$ cell proliferation than THP isolated from non-pregnant urine by salt precipitation (22). The sugar moiety was assumed to be responsible for the observed immunosuppressive differences.

Garcia et al. (23) studied the adhesion of $\mathrm{CaOx}$ monohydrate crystals to renal cells in the presence of THP or UM. The adhesion of crystals coated with THP to monolayer cultures of nontransformed monkey renal epithelial cells (BSC-1 line) was decreased by $30 \%$. However, adhesion of $\mathrm{CaOx}$ crystals coated with UM did not differ from that of uncoated crystals. Sialic acid residues may be important for this action of THP because neuraminidase treatment abolished the effect (23).
In the present study, we used absorbance at $630 \mathrm{~nm}$ that represents an exact measure of particle concentration per unit volume (24), and a Coulter Counter to assess nucleation and aggregation of $\mathrm{CaOx}$ crystals. The latter tech-
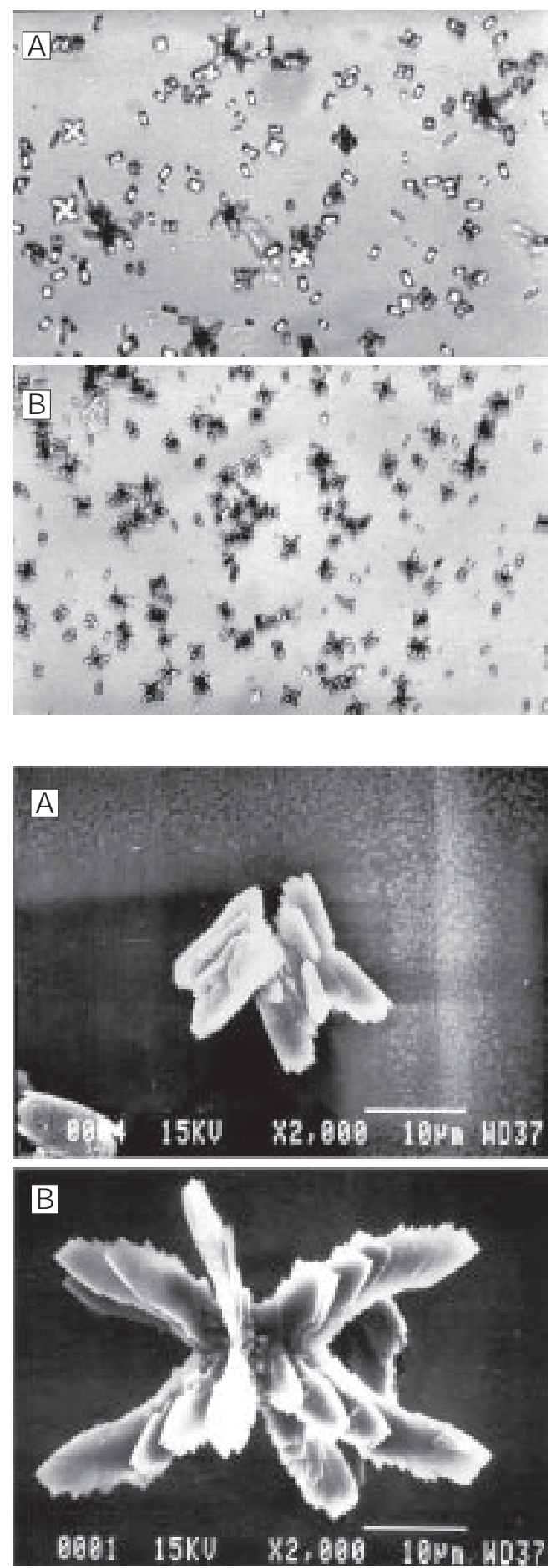

Figure 4. Effects of uromodulin from normal men $(A)$ and stone formers (B) on calcium oxalate crystallization (light microscopy, 500X).

Figure 5. Effects of uromodulin from normal men $(A)$ and stone formers (B) on calcium oxalate crystallization (scanning electron microscopy). 
nique was devised by Robertson and Peacock and modified by Ryall et al. (18). The results showed a different effect of THP and UM on $\mathrm{CaOx}$ crystallization. As demonstrated in Table 2, UM produced fewer particles than THP in all groups and the total volume of crystals produced by UM was larger than that produced by THP. In addition, THP decreased the diameter of the particles formed, mainly in the stone former group.

All experiments were confirmed by light and scanning electron microscopy (Figures 2-5). THP maintained the preferred structure in this calcium-rich system, forming octahedral crystals typical of $\mathrm{CaOx}$ dihydrate. In- terestingly, UM caused the crystal structure to exhibit marked polymorphism. Our data agree with those reported by Wesson et al. (19), who stated that the formation of $\mathrm{CaOx}$ dihydrate crystals offers a potential biological advantage by decreasing the affinity for the inner medullary collecting duct cell membrane surface, the region where symptomatic stones probably form.

These data support the view that the dual role of THP and UM suggests different functions. Under the conditions of this assay system, THP affects nucleation and inhibits crystal aggregation while UM may promote aggregation of highly polymorphic $\mathrm{CaOx}$ crystals.

\section{References}

1. Coe FL \& Parks J H (1997). New insights into the pathophysiology and treatment of nephrolithiasis: new research venues. J ournal of Bone and Mineral Research, 12: 522-533.

2. Hess B \& Kok DJ (1996). Nucleation, growth, and aggregation of crystals. In: Coe FL, Favus MJ, Pak CY, Parks J H \& Preminger GM (Editors), Kidney Stones. Medical and Surgical Management. Lippincott-Raven, Philadelphia, PA, USA.

3. Robertson WG \& Peacock M (1972). Calcium oxalate crystalluria and inhibitors of crystallization in recurrent renal stone formers. Clinical Science, 43: 499-506.

4. Rose MB (1975). The inhibitory effect of urine on calcium oxalate precipitation. Investigative Urology, 12: 428-433.

5. Nakagawa Y, Abram V, Parks J H, Lau S-H, Kawooya J K \& Coe FL (1985). Urine glycoprotein crystal growth inhibitors. Evidence for a molecular abnormality in calcium oxalate nephrolithiasis. J ournal of Clinical Investigation, 76: 1455-1462.

6. Worcester E (1996). Inhibitors of stone formation. Seminars in Nephrology, 16: 474-486.

7. Hoyer J R \& Seiler MW (1979). Pathophysiology of Tamm-Horsfall protein. Kidney International, 16: 279-289.

8. Kumar S \& Muchmore A (1990). TammHorsfall protein-uromodulin (1950-1990). Kidney Intemational, 37: 1395-1401.

9. Worcester EM, Nakagawa Y, Wabner CL, Kumar S \& Coe FL (1988). Crystal adsorption and growth slowing by nephrocalcin, albumin and Tamm-Horsfall protein. American J oumal of Physiology, 255: F1197-F1205.
10. Hess B (1994). Tamm-Horsfall glycoprotein and calcium nephrolithiasis. Mineral and Electrolyte Metabolism, 20: 393-398.

11. Hess B, Nakagawa Y, Parks J H \& Coe FL (1991). Molecular abnormality of TammHorsfall glycoprotein in calcium oxalate nephrolithiasis. American J ournal of Physiology, 260: F569-F578.

12. Muchmore AV \& Decker J M (1985). Uromodulin: A unique $85 \mathrm{kD}$ immunosuppressive glycoprotein isolated from urine of pregnant women. Science, 229: 479-481.

13. Pennica D, Kohr WJ, Kuang WJ , Glaister D, Aggarwal BB, Chen EY \& Goeddel DV (1987). Identification of human uromodulin as the Tamm-Horsfall urinary glycoprotein. Science, 236: 83-88.

14. Lieske J C \& Coe FL (1996). Urinary inhibitors and renal formation. In: Coe FL, Favus MJ, Pak CY, Parks JH \& Preminger GM (Editors), Kidney Stones. Medical and Surgical Management. Lippincott-Raven, Philadelphia, PA, USA.

15. Porile J L, Asplin J R, Parks J H, Nakagawa Y \& Coe FL (1996). Normal calcium oxalate crystal growth inhibition in severe calcium oxalate nephrolithiasis. J ournal of the American Society of Nephrology, 7: 602-607.

16. Tamm I \& Horsfall FL (1950). Characterization and separation of an inhibitor of viral hemagglutination present in urine. Proceedings of the Society for Experimental Biology and Medicine, 74: 108-114.

17. Achilles W (1997). In vitro crystallization systems for the study of urinary stone formation. World J oumal of Urology, 15: 244-251.

18. Ryall RL, Bagley CJ \& Marshall VR (1981).
Independent assessment of the growth and aggregation of calcium oxalate crystals using the Coulter Counter. Investigative Urology, 18: 401-405.

19. Wesson JA, Worcester EM, Wiessner J H, Mandel NS \& Kleinman J G (1998). Control of calcium oxalate crystal structure and cell adherence by urinary macromolecules. Kidney International, 53: 952-957.

20. Dussol B \& Berland Y (1996). Urinary kidney stone inhibitors. Where are we? Nephrology, Dialysis, Transplantation, 11: 1222-1224.

21. Hess B, J aggi $M$, Zipperle $L \&$ J aeger $P$ (1995). Reduced carbohydrate content of Tamm-Horsfall glycoprotein (THP) from severe recurrent renal calcium stone formers (RCSF). J ournal of the American Society of Nephrology, 6: 949 (Abstract).

22. Hession C, Decker JM, Sherblom AP, Kumar S, Yue CC, Mattaliano RJ , Tizard R, Kawashima E, Schmeissner U \& Heletky S (1987). Uromodulin (Tamm Horsfall glycoprotein): A renal ligand for lymphokines. Science, 237: 1479-1484.

23. Garcia WE, Lieske JC, Nakagawa Y \& Toback FG (1998). Tamm-Horsfall protein, but not uromodulin, inhibits adhesion of calcium oxalate monohydrate (COM) crystals to renal cells. J ournal of the American Society of Nephrology, 9: 554 (Abstract).

24. Hess B, Meinhardt U, Zipperle L, Giovanoli R \& J aeger P (1995). Simultaneous measurements of calcium oxalate crystal nucleation and aggregation: impact of various modifiers. Urological Research, 23: 231-238. 